\title{
Awareness-raising workshops on (geronto)technologies for elderly/ family care: contributions to knowledge
}

\author{
Oficinas de sensibilização sobre (geronto)tecnologias de cuidado ao idoso/família: contribuições ao conhecimento
} Talleres de sensibilización sobre (geronto)tecnologías para el cuidado de ancianos/familiares: contribuciones al conocimiento

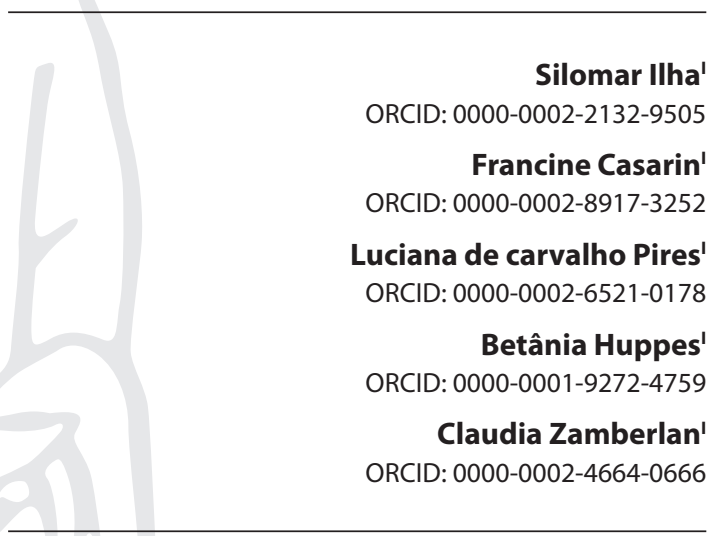

'Universidade Franciscana. Santa Maria, Rio Grande do Sul, Brazil.

How to cite this article:

Ilha S, Casarin F, Pires LC, Huppes B, Zamberlan C. Awareness-raising workshops on (geronto)technologies for elderly/family care: contributions to knowledge.

Rev Bras Enferm. 2020;73(Suppl 3):e20200264. doi: http://dx.doi.org/10.1590/0034-7167-2020-0264

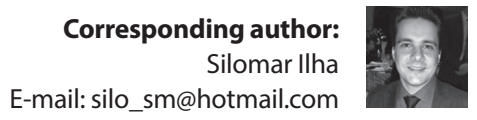

EDITOR IN CHIEF: Antonio José de Almeida Filho ASSOCIATE EDITOR: Hugo Fernandes

Submission: 05-14-2020 Approval: 09-14-2020

\begin{abstract}
Objective: to describe the contributions of awareness-raising workshops to the knowledge of students in health courses about care (geronto)technologies for elderly people/family. Methods: a strategic action research, developed with 12 students from the last semester of nursing, physiotherapy, dentistry and occupational therapy from a university in Rio Grande do Sul, Brazil. Data were collected from September to December 2019, through semi-structured interviews, before and after awareness-raising workshops, and submitted to content analysis. Results: the analyzed data, before the workshops, allowed constructing two categories that dealt with lack of knowledge and non-use of care (geronto)technologies. After the workshops, five categories made it possible to understand (geronto)technologies in the form of products and in the form of processes/strategies/knowledge. Conclusion: carrying out awareness-raising workshops contributed to knowledge production regarding the conceptual aspect and identification of their usefulness in the care setting. Descriptors: Aged; Family; Technology; Health Education; Health Personnel.
\end{abstract}

\section{RESUMO}

Objetivo: descrever as contribuições de oficinas de sensibilização para o conhecimento dos acadêmicos dos cursos da área da saúde acerca das (geronto)tecnologias de cuidado à pessoa idosa/família. Métodos: pesquisa-ação estratégica, desenvolvida com 12 acadêmicos do último semestre de enfermagem, fisioterapia, odontologia e terapia ocupacional de uma universidade do Rio Grande do Sul, Brasil. Os dados foram coletados de setembro a dezembro de 2019, mediante entrevista semiestruturada, antes e após oficinas de sensibilização, submetidos à análise de conteúdo. Resultados: os dados analisados, antes das oficinas, permitiram a construção de duas categorias que versaram sobre o desconhecimento e a não utilização de (geronto)tecnologias de cuidado. Após as oficinas, cinco categorias possibilitaram a compreensão das (geronto)tecnologias na forma de produto e na forma de processo/estratégias/conhecimento. Conclusão: as oficinas de sensibilização contribuíram para produção do conhecimento no que se refere ao aspecto conceitual e na identificação da sua utilidade no cenário de cuidados.

Descritores: Idoso; Família; Tecnologia; Educação em Saúde; Pessoal de Saúde.

\section{RESUMEN}

Objetivo: describir los aportes de los talleres de sensibilización al conocimiento de los académicos de los cursos de salud sobre las (geronto)tecnologías de atención al anciano/familia. Métodos: investigación acción estratégica, desarrollada con 12 académicos del último semestre de enfermería, fisioterapia, odontología y terapia ocupacional en una Universidad de Rio Grande do Sul, Brasil. Los datos fueron recolectados de septiembre a diciembre de 2019, mediante entrevistas semiestructuradas, antes y después de los talleres de sensibilización, sometidos a análisis de contenido. Resultados: los datos analizados, antes de los talleres, permitieron la construcción de dos categorías que abordaron el desconocimiento y el no uso de (geronto) tecnologías de cuidado. Después de los talleres, cinco categorías permitieron entender las (geronto)tecnologías en forma de productos y en forma de procesos/estrategias/conocimientos. Conclusión: los talleres de sensibilización contribuyeron a la producción de conocimiento sobre el aspecto conceptual y la identificación de su utilidad en el escenario assistencial. Descriptores: Anciano; Familia; Tecnología; Educación en Salud; Personal de Salud. 


\section{INTRODUCTION}

Training and education have been prominent issues in the context of education and health policies, in order to ensure qualified training of health professionals and, consequently, professional care with higher quality and resolution ${ }^{(1)}$. The Brazilian National Curriculum Guidelines (DCNs - Diretrizes Curriculares Nacionais) have guided the need for training generalist, humanized, critical and reflective health professionals ${ }^{(2)}$.

It becomes clear, in this context, the need to train professionals committed to the health system who are able to plan interventions to promote, prevent and rehabilitate individuals', families' and communities' health. Therefore, professional training must accompany the movements and configurations of society ${ }^{(3)}$.

In the last decades, it has been perceived, more accentuated, the population aging, understood as a worldwide phenomenon in significant growth. In 2018, the Brazilian aging index (AI) was 63 elderly people for every 100 young people. Statistics indicate that in 2031, there will be 102.3 elderly people for every 100 young people and that, in 2055, Brazil will have 202 elderly people for every 100 young people ${ }^{(4)}$.

Thus, it is understood that the training of Brazilian professionals in the field of health must be aligned with the Brazilian National Health Policy for Elderly People (PNSPI - Política Nacional de Saúde da Pessoa Idosa). PNSPI in its guidelines, values permanent qualification with regard to the health of these people, in order to encourage developing research and teaching on the aging process ${ }^{(5)}$. Realizing the reality experienced by elderly people and families, as well as the importance of an integrated performance in the context of gerontology, some professionals and teaching and health institutions have invested efforts in understanding and using care technologies.

From the concepts of technology, gerontology and complexity, Brazilian nurses have implemented complex care-educational (geronto)technologies. They are understood as "every product, process, strategy, service and/or knowledge, with the care-educational purpose of elderly people and their family members/ caregivers, the result of a complex collective construction/experience, which values relationships, interactions and feedback from those involved, through inter-multi-trans-meta-disciplinary knowledge"(6).

(Geronto)technologies, by their nature, suggest a need for interdisciplinary and transdisciplinary professional approaches, with a view to assisting elderly people and family members/caregivers in daily care, which has unique, multidimensional and complex characteristics $^{(7)}$. Thus, it is necessary to know what students in health courses understand about care (geronto)technologies, with a view to identifying possible knowledge gaps. These gaps can be minimized with the implementation of interventions aimed at deepening knowledge and, therefore, greater possibility of caring for people/families.

It is understood that, in this way, one can contribute to training future professionals and with science, by expanding knowledge about tool use, to assist in the daily care of elderly people/ families. Among the possible methodologies for this purpose, awareness-raising workshops/training stand out, as they provide opportunities for participatory construction, the exchange of experiences and knowledge between participants. The workshops enable the construction of groups, where participants are willing to work in cooperation, with a view to (re) constructing the situations experienced $^{(8)}$.

In this context, it is necessary to evaluate the contribution of awareness-raising workshops/training to the training of future professionals in the health field, through the production of knowledge and/or deepening of it, a fact that justifies the need and relevance of this search. Due to the understanding that issues related to elderly people's health and technologies are necessary in the context of health, being highlighted, by the Ministry of Health (MoH), as research priorities in $\mathrm{Brazil}^{\left({ }^{(9)}\right.}$.

Based on these considerations the question is: what are the contributions of awareness-raising workshops to the knowledge of students in health courses about care (geronto)technology for elderly people/family?

\section{OBJECTIVE}

To describe the contributions of awareness-raising workshops to the knowledge of students in health courses about care (geronto)technologies for elderly people/family.

\section{METHODS}

\section{Ethical aspects}

This research is part of a macro project called "Cuidado ao idoso/ família com a Doença de Alzheimer: pesquisa-ação com students dos cursos da saúde". The general objective was to raise awareness among students in the health field about elderly/ family care with Alzheimer's Disease and care (geronto)technology use. This article addresses one of the specific objectives of the project.

This study was submitted to appreciation of a Research Ethics Committee with Human Beings (REC), via Plataforma Brasil (Brazil Platform), REC/CONEP system. Only after REC approval, did the first contact with participants take place. Ethical and legal precepts involving research with human beings were considered, according to Resolution 466/12 of the Ministry of Health ${ }^{(10)}$. The project was approved by REC and CAAE (Certificado de Apresentação para Apreciação Ética - Certificate of Presentation for Ethical Consideration). Participants signed the Informed Consent Form (ICF), in two copies. One stayed with participants and the other stayed with researchers. Participant anonymity was maintained, identified by letter $S$ (student), followed by a number (S1, S2... S12).

\section{Type of study}

It is a strategic action research, which proposes a transformation based on the researcher's knowledge about a given reality. In this type of research, the transformation is previously planned by the researcher, who monitors the effects and evaluates the results of their application ${ }^{(11)}$. To guide the methodology, the Consolidated criteria for reporting qualitative research (COREQ), found in the Enhancing the QUAlity and Transparency Of health Research (EQUATOR), was used. 


\section{Methodological procedures}

\section{Study setting}

The study was conducted at a university located in Rio Grande do Sul State, Brazil. This entity is 65 years old and has 35 undergraduate courses, eight of which are in the health field.

\section{Data source}

The research was proposed with students from nursing, pharmacy, physiotherapy, nutrition, dentistry and occupational therapy courses. Participants were selected by lot in the call list, at which point the invitation was made to five scholars from the last semesters of each course. Initially, through call, which was made available to researchers by professors in charge of the semester in which students were in, a random draw took place. The selected students were contacted by the researchers within the university, and invited to participate in the research. After acceptance, dates and times for data collection were scheduled.

The initial choice of the expected number of participants was due to the understanding that it was a sufficient number to have a projection of students' knowledge. However, saturation sampling was considered so that if, at the end of the interviews with the initially expected number, new information was still emerging, a new selection of participants could be considered. Students from the last semesters were selected, as they had already studied the subjects that deal with the theme of aging in their undergraduate course, in addition to having already experienced different realities offered during their training process.

Students from one of the aforementioned health courses were included, those taking the last semester of the course and who have already taken courses related to gerontology, geriatrics, neurology or equivalent, according to each course. Therefore, students who were not in the classroom on the date of the draw were excluded, for various reasons, such as medical certificate, student exchange, among others. Initially, 24 students accepted to participate in the study; however, 12 remained until the end of the study, and, considering the data saturation criterion, made up the corpus of this research, which represented the nursing, physiotherapy, dentistry and occupational therapy courses.

\section{Data collection and organization}

Data collection was carried out at two different times. In the first phase (moment 1), a semi-structured interview was applied to identify the knowledge of students in health courses about care (geronto)technologies for elderly people/family. This moment occurred individually with each participant in a university classroom, by prior appointment, from September to October 2019.

Data collection was performed using a tool, developed specifically for this research, which was divided into two parts, the first referring to the characterization of the participants. In the second part, the questions were presented: have you heard/read something about (geronto)technologies? Have you ever used some kind of (geronto)technology? Which (geronto)technologies can be adopted by a family member/caregiver to assist them in the daily care of elderly people? This first moment allowed identifying knowledge gaps, and, therefore, aroused the need for intervention.

Thus, after data collection (moment 1), the development of workshops was scheduled, together with the participants, for November 2019, with a view to raising awareness/training of students on issues related to care (geronto)technologies in the context elderly people/family. The workshops were held from a conversation round in a classroom at that university, with an average duration of one and a half hours. The activity was coordinated by one of the researchers, who is a nurse specialist in gerontology, a researcher in the field of aging.

The researchers started the workshop by welcoming the participants and thanking them for participating in the research. To assist the activity, the audiovisual resource was used, at which time the researchers were explaining aspects related to aging and about educational-care (geronto)technologies, expanding some points and deepening others, as they perceived the need or were requested by participants. All students were instructed that, when they felt the need, they could contribute to the workshop, bringing possible personal experiences or that had been learned during the training process.

After the awareness-raising workshops/training, dates and times for data collection (time 2) were scheduled for November and December 2019, which was conducted by the same tool used in time 1, in order to identify the contribution of awareness-raising workshops to students' knowledge about care (geronto) technologies for elderly people/family. It should be noted that all interviews were recorded with an MP3 player. Afterwards, they were transcribed in full, mechanographically by the researchers, with the aid of the Microsoft Word program (version 16.31), enabling data analysis.

\section{Data analysis}

The data from the interviews were submitted to content analysis $^{(12)}$ in three steps. Initially, pre-analysis was carried out, by general reading of all the material, called skimming, in order to allow a comprehensive content view. Then, in material exploration, a full and in-depth reading of the interviews was carried out, which enabled transcription of results and significant passages. Afterwards, codification of findings was developed, which allowed developing the categories presented in Figure 1.

\section{RESULTS}

Of the 12 survey participants, 11 were female and one male, aged between 20 and 37 years. Of these, four were studying nursing; five, dentistry; two, occupational therapy; one, physical therapy. The data analyzed before the awareness-raising workshops/training allowed constructing two categories that dealt with lack of knowledge and non-use of care (geronto)technologies. After the workshops, the data allowed the understanding of (geronto)technologies in the form of products and in the form of processes/strategies/knowledge, which resulted in five categories (Figure 1). 


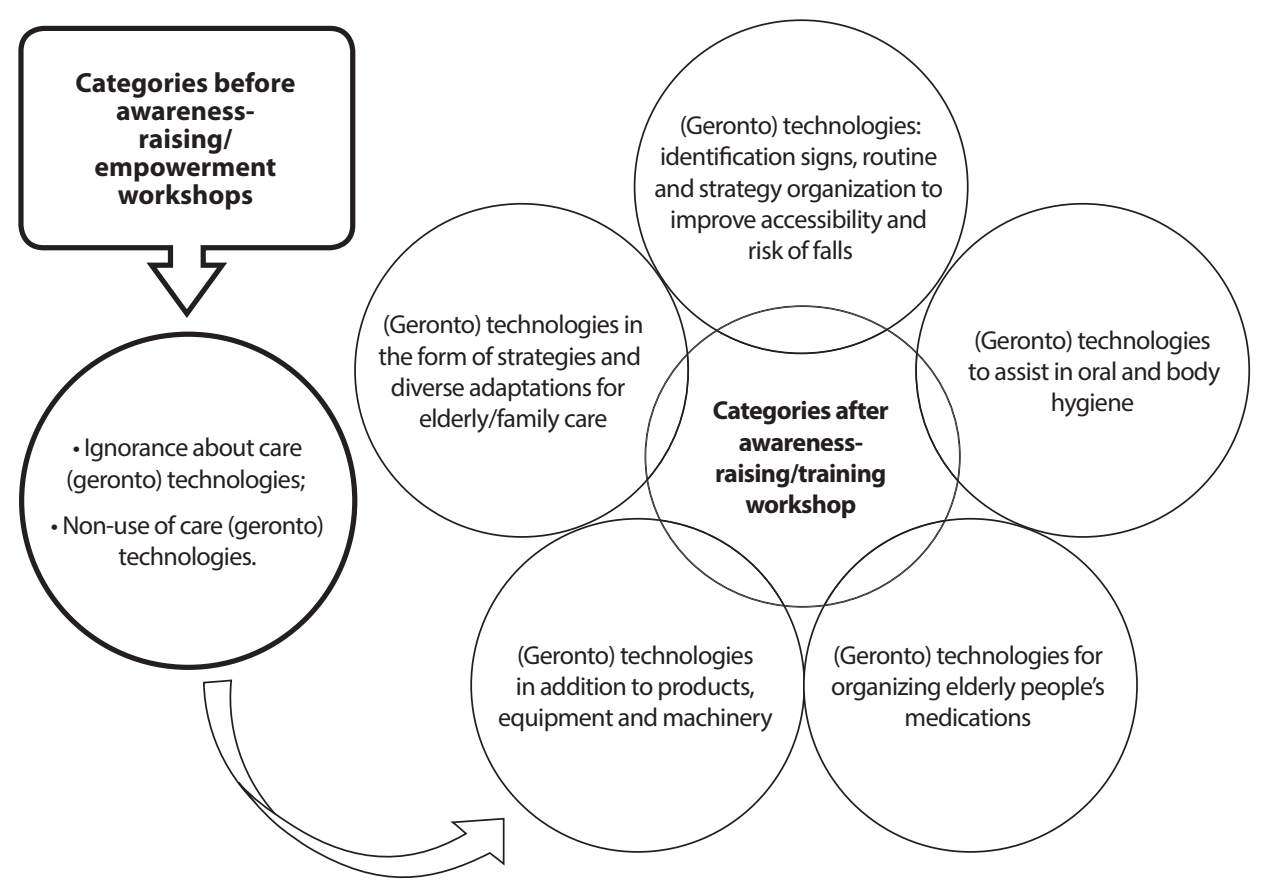

Figure 1 - Schematic demonstration of all categories

\section{Ignorance about care (geronto)technologies}

Before awareness-raising workshops/training, research participants were unaware of issues related to (geronto)technologies. Two students, S1 and S5, from the word analysis, suggested the (geronto)technology as education with family members/caregivers and as a technology to assist elderly people, through apparatus or humanized care:

I don't know very well, more, by the word, it seems to be an education together with family members and caregivers. [...] (S1)

I have no idea. (S2)

I don't know, geronto comes from an elderly person; technology is an innovation [...] perhaps a device or humanized care. (S4)

I do not know the term itself, associating the word, I believe it is some technology that can be developed to help elderly people. [...] (S5)

I don't know what they are. (S6)

I have no idea. (S7)

I have no knowledge. (S8)

I never heard of that word, in (geronto)technology. (S9)

\section{Non-use of care (geronto)technologies}

Before awareness-raising workshops/training, participants said they believed they had never used care (geronto)technologies:

No, I think the caregiver is the one who deals with this most. (S1)

I have no way of answering this question, I have no idea. (S2)
No, I don't think so. (S3)

Maybe so, but I don't know if it would fit into the (geronto)technologies. (S6)

Not that I know of. (S8)

I didn't, I never used it. (S11)

I do not think so. (S12)

After the awareness-raising workshops/training, it was possible to perceive a change in the students' knowledge about care (geronto)technologies, as one can perceive an expansion and deepening both about the concept and about its use. Such information can be seen in the next six categories, the first two of which deal more with conceptual issues, while the last four categories refer to students' understanding of having already used (geronto) technologies.

\section{(Geronto)technologies in the form of strategies and diverse adaptations for elderly/family care}

After the awareness-raising workshops/training, some students referred to (geronto)technology as I felt different strategies and adaptations for elderly care:

[...] now I know, they are techniques, I don't know if I can use that term, but it improves that person's quality of life, not only who is diagnosed with Alzheimer's Disease, but also who cares, who participates, are alternatives for give better comfort in everyday life [...] my grandmother had Alzheimer's. So, after the workshops, I realized that what her daughter was doing, even without knowing $i t$, was (geronto)technologies. She created alternatives, created techniques, so to speak, to help [...] there, with training, I was surprised by the amount of things we can do to help the whole family. (S3)

[...] all strategies that have an effect are (geronto)technology for elderly people, environmental issues, everything that favors elderly people, such as medication. Abox with the morning medication schedule can be made by placing a sun, afternoon medication, by placing a coffee, a photo with coffee; at night, the moon can be set. It is a strategy, but, if there is an effect, it becomes a (geronto)technology to assist elderly people and family members/caregivers, a technology. (S4)

So, I had no idea, but it's such a simple thing, it's the changes you have to make at home. In this case, even the stimulation of a person with Alzheimer's, with cocktail magazines and such, changes at home that you can make. (S7)

Now, after training, I know that these are resources that can be created to help patients with Alzheimer's Disease and that when effects arise, they are considered (geronto)technologies. (S10) 
Now they are tools that can be used to make life easier for elderly people and family members/caregivers. My knowledge comes from geriatric dentistry and training. (S11)

\section{(Geronto)technologies in addition to products, equipment and machinery}

Furthermore, it was possible to perceive, in the speeches of some participants, that, before the workshops, when they thought about technology for elderly care, they associated them only with those in the form of products, such as assistive technologies, software, robots and devices. After the workshops, it was noticed that the knowledge was expanded, because in addition to the (geronto)technologies in the form of product, the participants also began to understand the various strategies used to improve coexistence and care for elderly people.

I didn't know, until I had that training, in which it was explained what the technological (geronto) are. I understand how the various types of management and strategies that can be used, both with family members and with a person with Alzheimer's at home, say: in times of agitation, never fight back; adapt the furniture at home, strategies to help you remember to take the medication, with dates, with names, ways you can find on the card. There are several ways, in addition to assistive technology, for sure, which helps a lot, but they are strategies, so that the family can deal better with that person and have a better quality of life. (S1)

[...] after training, I saw that (geronto)technologies are very simple things to help elderly people. I never imagined that, for example, the strategies for elderly people to remember to take the medication on a daily basis were (geronto)technologies, I imagined that (geronto)technologies were just things like software, which was a technology that helped, but not something so simple and routine. (S2)

I swear, before training, I thought I was a robot, I thought of a robot [laughs]. But now, after training, I saw that it is planning by the family and professionals, who organize the patient's daily life. Within them, there is, for instance, the bath scheme, medication scheme, something related to the daily life of patients with Alzheimer's. [...] (S5)

I didn't know, but after training, I know! I had the impression, before training, that (geronto)technologies were more a question of devices and such. But I saw that it can be any attitude planned for the good of elderly people who have this disease, for instance, a sign saying "here is the bathroom, here is such a thing", so it is any action for elderly people with Alzheimer's to be able to live better with this disease [...] my knowledge comes from training. (S8)

It is a word that we did not use, so (geronto)technologies are technologies that the interdisciplinary health team, composed of occupational therapist, physiotherapist, nurse, pharmacist, physicians and other professionals, use to work with elderly people, to facilitate the routine of elderly people. They can be either a cell phone program, or techniques that you will do at home, adaptations at their homes, signs. These are technologies that we are studying to improve both the social participation of elderly people, improve the routine, improve their performance in activities of daily living, to make this elderly person always independent and autonomous. Caregivers can also be guided to make these adaptations, this management at home with elderly people, regardless of whether they have Alzheimer's or not. (S9)

\section{(Geronto)technologies for organizing elderly people's medications}

Some participants reported having used (geronto)technologies for organizing elderly people's medications.

I found it very interesting and used it to organize the medications, as was said during the training. Are strategies for patients to be able to identify by number, by day, by date, by color, forms of medication to be taken. [...] (S1)

I already used it, it was in the matter of medication organization, I organized it in pots, I used it on the internship right after I learned in training. [...] (S4)

On the other hand, in the organization of medications, facilitating the daily life of the elderly patient, such as separating the medications in the morning by identifying them with a sun; the afternoon medications, identified with an image of a sign of food, resembling lunch; and, in the medication of the night, a moon. (S5)

[...] medication organization, I was even able to use this week now in my internship, because I had to go to someone's house, and they were illiterate, and then I took and created, you know, identified morning medication with a rising sun; the afternoon, I put an " $A$ " out of afternoon and a sun; and put a moon on for the night remedies. On the medication chart, l even put the numbers of how many times I had to take it. I got the idea of training. He, the elderly man, was very happy, then we explained what it was like each day, each shift, what he had to do. We would talk to him, and he would repeat it, and we would reinforce it more and more to see if he really understood what times he had to take the medication. Before that, he was unable to take, because he did not remember and also did not know how to read, the training helped me a lot. (S7)

Next week I'll use more. I will organize the medication in the morning, afternoon and evening with a patient who has many weaknesses and does not remember the medication schedule. (S12)

\section{(Geronto)technologies to assist in oral and body hygiene}

The negotiations used for elderly people to accept oral and body hygiene were also mentioned as care (geronto)technologies, used by students. These are products and strategies used with a view to better acceptance of care, such as dolls and adapted brushes. In the speech of S10, it was possible to perceive, in addition to (geronto)technologies in the form of products, those that present themselves in the form of strategies and knowledge. For instance, it was used in a situation in which elderly people were confused, asking them to take them to their home, and they were in that environment. In this condition, S10 says that elderly people can be removed from the environment, on foot or by car, so that they forget the reason for the confusion. Moreover, S10 stresses that one should not contradict the ideas of elderly people at the time of mental confusion, so that they do not become aggressive. 
I already used it in the third stage of Alzheimer's Disease! She had a doll and to be able to play with it, she would have to bathe first, because the doll doesn't like dirt. So, she encouraged herself to do things for the doll. I think it is a big failure in our preparation to serve elderly people with special needs, now I would know how to assist due to training. (S3)

[...] adapted brushes [...] bath negotiations, creating a table, when elderly people with Alzheimer's disease want to go home, you can take a walk with them, either on foot or by car, never contradict their ideas as they will become aggressive, I found it very interesting and everyone should know. (S10)

[...] yes, i already used it in my area, negotiating with elderly people, as shown in the training. For example, if an elderly patient with Alzheimer's performs oral hygiene, they will gain something in return. An adapted toothbrush can also be used. (S11)

\section{(Geronto)technologies: identification signs, routine and strategy organization to improve accessibility and risk of falls}

Signs for identifying objects and rooms, routine organization and strategies to improve accessibility and decrease the risk of injury to elderly people were also, after awareness-raising workshops/training, emphasized as care (geronto)technologies. S9 mentions, as (geronto)technologies, the guidelines and routine clothing together with elderly people

[...] we always had to create strategies, because she, elderly people, tried to run away from home, we had to find a way for her not to arrive at the doors, take the keys, because she has already opened the door and left the house alone [...]. There is also the issue of adaptations that occupational therapy makes to improve accessibility to the bathroom, bedroom, so that it does not hurt, and the brushes and cutlery adapted. (S1)

[...] we put signs with the name bathroom and a color photo you know, we took all the things that made it difficult for him, who is elderly, remember [...] why he lives alone, family lives far away, so it's just him and needs to turn around. We were able to help and that was very good, the training came at the right time. (S7)

Yes, I have already used identification signs for rooms and objects. [...] (S8)

I already used [...] it was through guidelines and routine confections together with the patient elderly people, to help her remember her commitments; if the person is in a more advanced stage, it will have to be with the responsible caregiver [...] / also used some cognitive stimulus activities. (S9)

Other (geronto)technologies referred to products used to assist in the safety of elderly people in their daily lives, such as handrails on stairs, rounding corners of furniture, non-slip tapes and the knowledge associated with removing carpets.

[...] we also adapted the corners of the furniture, we removed the carpet. [...] (S1)

Yes, I used it with our elderly people patients, how to put a handrail, non-slip tape on the floor to avoid the risk of falling and removing carpets. (S6)

\section{DISCUSSION}

The care context is singular, uncertain, complex, being modified due to the complexity that surrounds $i^{(13)}$. Such attitudes sometimes enhance the production/construction and use of care technologies understood, in the context of elderly people, as (geronto)technologies ${ }^{(14)}$. However, in order for them to reach their maximum potential in the care process for elderly people, it is necessary to invest in the teaching-learning process of health professionals, through interventional learning methodologies.

This statement corroborates what was evidenced in the present research, because, before the intervention, through awareness-raising workshops/training, students were unaware of issues related to educational-care (geronto)technologies. After the workshops, there was an expansion and, at the same time, a deepening of knowledge on the theme.

A research developed aiming at identifying the contributions of pedagogical workshops in the formation of the interlocutor of continuous education in health demonstrated that workshops are characterized by dynamic spaces that allow a creative process of collective learning and transformation of all participants involved. In workshops there are exchanges of experiences, bonding, construction and production of theoretical and practical knowledge in an active and reflective way, based on the analysis of reality and the construction of new knowledge $\mathrm{e}^{(15)}$.

This research showed that, before awareness-raising workshops/training, when students thought about technology for elderly care, they associated them only with those in the form of products, such as assistive technologies, software, robots and devices. After the workshops, knowledge was expanded, as the participants also began to understand the various strategies and adaptations used to improve the coexistence and care of elderly people, which denotes the contribution of the workshops to the students' teaching-learning process.

A study developed with family members/caregivers of elderly people participating in a support group identified (geronto) technologies in two groups: one with their presentation in the form of a product; the other in the form of process/knowledge/ strategies, for caring for/living with elderly people. Thus, it became evident that (geronto)technologies are sometimes not palpable products, but the result of work that involves a set of actions that aim at health care ${ }^{(14)}$.

Before awareness-raising workshops/training, students reported believing that they had never used the educational-care (geronto) technologies. After the workshops, it was possible to perceive an expansion and deepening of the students' knowledge, because, when the interviews were remade, they reported having used (geronto)technologies, aiming at organizing elderly people's medications. Similar data has been identified in other research, which demonstrated various types of (geronto)technologies in the form of a product and a strategy for the control and care of medications $^{(7,14)}$.

A study carried out with health/humanities professors and students, participating in a support group, showed that the strategies, ideas, tools, studies, methods and tools used to produce knowledge within the group and improve care practice in the context of elderly people were care (geronto)technologies ${ }^{(7)}$. Other 
(geronto)technologies used by participants, after awareness-raising workshops/training, referred to products used to assist elderly people in their daily lives. They contributed to their safety, such as handrails on stairs, rounding corners of furniture, non-slip tapes and the knowledge associated with removing carpets.

A study carried out with the objective of identifying (geronto) technologies developed/used by family members/caregivers as complex care strategies for elderly people/family with $A D$ also presented support bars, handrails on stairs, removal of carpets and various negotiations with elderly people, as care (geronto) technologies for these people, as well as for family members/ caregivers $^{(14)}$.

The negotiations used for elderly people to accept the performance of oral and body hygiene were also mentioned as care (geronto)technologies by students, participating in this research. These are products and strategies used to improve the acceptance of care, such as dolls, adapted brushes, among others. A similar data was found in research developed with the objective of knowing the challenges and care technologies developed by caregivers of people with Alzheimer's Disease (AD), which presented strategies used as (geronto)technologies by caregivers, among which, use of dolls and adaptations at home ${ }^{(16)}$.

A participant socialized the experience of using a (geronto) technology in the form of a process/knowledge/strategy, in a situation in which elderly people were confused, asking them to take it to their home, the same being was in that environment. For this situation, a student referred to the need to remove elderly people from the environment, walking or driving, so that they would forget the reason that led to such confusion. Moreover, this participant stressed that elderly people should not be opposed when they are confused, as this attitude may make them aggressive.

This data was also evidenced in a research that aimed to know the difficulties experienced by family caregivers of elderly people with $A D$ and to develop strategies that meet the difficulties experienced in the care process for these people. The strategy built for this situation was not to upset the person, not to make him or her nervous, but to tell him or her that he or she will take him or her home, walk around the block, walking or driving and returning home entering, if possible, through a different door than the one that came out ${ }^{(17)}$.

Signs for identifying objects and rooms, organizing the routine and strategies to improve accessibility and reduce the risk of injury to elderly people were also mentioned as care (geronto) technologies, after awareness-raising workshops/training. It is evident, therefore, that using (geronto)technologies in elderly people's daily lives is an important tool that aims to encourage independence, autonomy and self-care, favoring the prevention and risk of falls ${ }^{(18)}$. We emphasize the need for the participation of family members/caregivers in this context, who must understand that elderly people have a history and have desires. Respecting their autonomy and independence is fundamental, as well as promoting necessary changes in the environment, so that elderly people can develop their daily routine with greater quality and safety ${ }^{(19)}$.
Thus, interventions aimed at the teaching-learning process of professionals or future professionals in the health field, focusing on the aging process, care and everything that involves it, such as (geronto)technologies, are fundamental. It is from knowledge that professionals acquire greater guidance conditions for family members/caregivers, which may result in better care for elderly people/family, in different contexts.

\section{Study limitations}

This research had some limitations. Among them is the fact that some participants did not continue the study until its completion, which restricted the initial group by half. However, data saturation proved to be sufficient for the final number of participants to reach the objectives of this research. Furthermore, there was a timid production regarding educational-care (geronto)technologies in the national and international context.

\section{Contributions to nursing and health}

This research showed potential to contribute to future professionals of courses in the health field, since it helped in the teaching process during the training of professionals from different nuclei, which, possibly, will have an impact on elder/family care through (geronto)technologies. Moreover, it is understood that it contributes to science, as it demonstrates a positive result after using awareness-raising workshops, and, in this way, it can serve as a model for other studies and research in different realities. It is suggested that further research be developed in order to contribute to the production of knowledge about various tools to assist elderly people/families in their daily care.

\section{FINAL CONSIDERATIONS}

This study is considered relevant, as it made it possible to describe the knowledge of students in health courses about (geronto)technologies for elder/family care before and after awareness-raising workshops. Before the workshop, there was a lack of knowledge about (geronto)technologies and their use. After conducting awareness-raising workshops, it was possible to identify knowledge production about the theme, both in its conceptual aspect and with regard to identification of its usefulness/use in care settings.

In the conceptual aspect, students came to understand them as different forms of products, tools, resources, techniques, strategies and alternatives that can be used to provide care to elderly people and family members/caregivers. They also started to identify the different (geronto)technologies that they had already used in caring for elderly/family, of which the different products and/or processes/knowledge/strategies stood out to assist in medication organization, in oral and body hygiene, and in routine organization, accessibility and safety of elderly people.

Thus, the contribution of awareness-raising workshops to the knowledge of students on issues related to using (geronto) technologies for elderly/family is shown, which can contribute to the care directed to these people in different settings. 


\section{REFERENCES}

1. Bahia SHA, Haddad AE, Batista NA, Batista SHSS. Health teaching as an object of research in academic graduate programs: an analysis of the Pro-Ensino na Saúde. Interface comunicação, saúde e educação. 2018;22(Supl.1):1425-42. doi: 10.1590/1807-57622017.0192

2. Treviso P, Costa BEP. The perception of professionals from the health area regarding their training as lecturers. Texto Contexto Enferm. 2017;26(1):e5020015. doi: 10.1590/0104-07072017005020015

3. Makuch DMV, Zagonel IPS. A integralidade do Cuidado no Ensino na Área da Saúde: uma revisão Sistemática. Rev Bras Educ Méd. 2017;41(4):515-24. doi: 10.1590/1981-52712015v41n4rb20170031

4. Instituto Brasileiro de Geografia e Estatística (IBGE). Tabela 2010-2060 - Projeção da População (revisão 2018$).$ Rio de Janeiro: IBGE, 2018.

5. Ministério de Saúde (BR). Portaria n. 2528/GM, de 19 de outubro de 2006. Aprova a Política Nacional de Saúde da Pessoa Idosa [Internet]. Brasília (DF): Ministério da Saúde; 2006. [cited 2020 Mar 30]. Available from: http://bvsms.saude.gov.br/bvs/saudelegis/gm/2006/\%20 prt2528_19_10_2006.html

6. Ilha S, Santos SSC, Backes DS, Barros EJL, Pelzer MT, Oliveira AMN. Educational and care-related (geronto) technology in Alzheimer's disease and in supporting the elderly/family: perspective of teachers and students. Esc Anna Nery. 2017;21(2):e20170039. doi: 10.5935/1414-8145.20170039

7. Ilha S, Santos SSC, Backes DS, Barros EJL, Pelzer MT, Costenaro RGS. Complex educational and care (geron)technology for elderly individuals/families experiencing Alzheimer's disease. Rev Bras Enferm. 2017;70(4):726-32. doi: 10.1590/0034-7167-2016-0687

8. Finocchiaro L, Imbrizi JM. Oficinas de arte e a formação em saúde: uma experiência no laboratório de sensibilidades da Universidade Federal de São Paulo (Unifesp) - Baixada Santista. Psicol Rev Belo Horizonte. 2017;23(1):274-91. doi: 10.5752/P.1678-9563.2017v23n1p274-291

9. Ministério da Saúde (BR). Agenda nacional de prioridades de pesquisa em saúde/Ministério da Saúde, Secretaria de Ciência, Tecnologia e Insumos Estratégicos, Departamento de Ciência e Tecnologia [Internet]. Brasília: Editora do Ministério da Saúde; 2018 [cited 2020 mar 30 ]. Available from: http://bvsms.saude.gov.br/bvs/publicacoes/agenda_prioridades_pesquisa_ms.pdf

10. Conselho Nacional de Saúde (BR). Diretrizes e normas regulamentadoras de pesquisa em seres humanos. Resolução n 466 , de 12 de dezembro de 2012.

11. Franco MAS. Pedagogia da pesquisa-ação. Educ Pesqui. 2005;31(3):483-502. doi: 10.1590/S1517-97022005000300011

12. Bardin L. Análise de conteúdo. Ed. São Paulo: Edições 70;2011. 229 p.

13. Backes DS, Zamberlan C, Colomé J, Souza MT, Marchiori MT, Erdmann AL, et al. Interatividade sistêmica entre os conceitos interdependentes de cuidado de enfermagem. Aquichan. 2016;16(1):24-31. doi: 10.5294/AQUI.2016.16.1.4

14. Ilha S, Santos SSC, Backes DS, Barros EJL, Pelzer MT, Gautério-Abreu DP. Gerontechnologies used by families/caregivers of elderly people with Alzheimers: contribution to complex care. Texto Contexto Enferm. 2018;27(4):e5210017. doi: 10.1590/0104-07072018005210017

15. Martins VP, Dorneles LL, Coloni CSM, Bernardes A, Camargo RAA. Contributions from pedagogical workshops to the interlocutor's training in continuing education in health. Rev Eletrôn Enferm. 2018;20(20):a147. doi: 10.5216/ree.v20.50148

16. Schmidt MS, Locks MOH, Hammerschmidt KSA, Fernandez DLR, Tristão FR, Girondi JBR. Challenges and technologies of care developed by caregivers of patients with Alzheimer's disease. Rev Bras Geriatr Gerontol. 2018;21(5):579-87. doi:10.1590/1981-22562018021.180039

17. Ilha S, Backes DS, Santos SSC, Gautério-Abreu DP, Silva BT, Pelzer MT. Alzheimer's disease in elderly/family: Difficulties experienced and care strategies. Esc Anna Nery. 2016;20(1):138-46. doi: 10.5935/1414-8145.20160019

18. Pereira JM, Hammerschmidt KSA, Siewert JS, Alvarez AM, Locks MOH, Heidemann ITSB. Gerontotechnology for fall prevention of the elderly with Parkinson. Rev Bras Enferm. 2019;72(Suppl 2):243-50. doi: 10.1590/0034-7167-2018-0704

19. Almeida FLSCP. O Envelhecimento e as relações sociais, políticas e familiares. Rev Longeviver [Internet]. 2019 [cited 2020 Mar 30];1(1):14-25. Available from: https://revistalongeviver.com.br/index.php/revistaportal/article/viewFile/757/818 